\title{
Immune mediated diseases in patients with celiac disease and their relatives: a comparative study of age and sex
}

\author{
Lorete Maria da Silva KOTZE ${ }^{1}$, Luiz Roberto KOTZE ${ }^{1}$, Isabela MORENO ${ }^{2}$ and Renato NISIHARA ${ }^{1,3}$
}

Received 29/5/2018 Accepted 8/9/2018

\begin{abstract}
Background - Up to 15\% of other immune-mediated diseases (IMDs) can occur in patients with CD throughout their lives and are associated with multiple factors, including sex and sex hormone levels. Moreover, sex is associated with differences in clinical presentation, onset, progression, and outcomes of disorders. Objective - To investigate the prevalence of IMDs at diagnosis in patients with celiac disease (CD) and their first-degree relatives and to compare the findings between female and male patients of different age. Methods - A retrospective study including Brazilian patients with CD who visited the same doctor during January 2012 to January 2017 was performed. Demographic and medical history data were collected through self-administered questionnaires and medical charts of the patients. In total, 213 patients were examined at diagnosis: 52 males (mean age, 40.0 years) and 161 females (mean age, 41.4 years). The patients were divided into two groups according to sex and age. Results - IMDs were observed in $60.2 \%$ of the female $(97 / 161)$ and $42.3 \%$ of the male patients $(22 / 52 ; P=0.22)$. However, the frequency of IMDs was significantly higher in females aged 51-60 years than in males with same age $(P=0.0002)$. Dermatitis herpetiformis $(\mathrm{DH})$ was significantly more prevalent in males $(P=0.02)$, whereas atopy was more prevalent in females $(P=0.02)$. IMDs observed in first-degree relatives were similar to those observed in patients $(70.9 \%$; $P<0.001)$, with a higher number observed in female relatives. Conclusion - The frequency of IMDs in CD patients was similar in all age groups and both sexes, except women diagnosed with CD after 51 years of age presented with an increased frequency of IMDs compared with males. Dermatitis herpetiformis was more prevalent in males, whereas atopy was more prevalent in females. No difference was observed in the type of IMDs between the first-degree relatives of both sexes.
\end{abstract}

HEADINGS - Celiac disease. Autoimmune diseases. Sex factors. Age factors. Dermatitis herpetiformis.

\section{INTRODUCTION}

Celiac disease (CD) is an autoimmune-mediated systemic disorder triggered by the ingestion of gluten - the protein fraction of wheat, barley, and rye - in genetically susceptible individuals. Up to $15 \%$ of other immune-mediated diseases (IMDs) can occur in patients with CD throughout their lives ${ }^{(1)}$. Diseases of the skin, endocrine, nervous system, liver, and rheumatological or connective tissues, among many other, are directly or indirectly related to the immune function ${ }^{(2-5)}$. Moreover, a significantly increased prevalence of $\mathrm{CD}(10-30$-fold) has been documented in individuals with different IMDs ${ }^{(2-5)}$.

IMDs and autoimmune diseases (AIDs) are associated with multiple factors, including sex and sex hormone levels. Moreover, sex is associated with differences in clinical presentation, onset, progression, and outcomes of disorders. Although the precise underlying reason remains unknown, sex hormone and chromosome abnormalities have been implicated to play roles in these sex-based differences. In addition, effects of environmental factors should be considered $^{\left({ }^{(}\right)}$. Sex-based differences in immune responses, which can affect both the innate and adaptive immune responses, contribute to differences in AID prevalence. In general, females exhibit a higher frequency of AIDs than males ${ }^{(7)}$. Several reports have shown a significantly increased prevalence of IMDs in the first-degree relatives of patients with CD compared with controls ${ }^{(8-10)}$.

In the present study, we investigated the prevalence of IMDs at diagnosis in patients with $\mathrm{CD}$ and in their first-degree relatives and compared the findings between female and male patients in different age groups.

\section{METHODS}

The research was approved by the Pontifical Catholic University of Paraná Ethical Committee. We performed a retrospective study including Brazilian patients with $\mathrm{CD}$ who visited a single private clinic over five years (2011-2016). Demographic and medical data were collected using patients' medical charts following clinical protocols and through self-administered questionnaires. Data regarding the family history of diseases, including IMDs previously reported in the literature ${ }^{(11,12)}$, were also collected.

All patients included in this study were newly diagnosed with $\mathrm{CD}$ on the basis of clinical complaints, positive screening with au-

Declared conflict of interest of all authors: none

Disclosure of funding: no funding received

${ }^{1}$ Universidade Federal do Paraná, Hospital de Clínicas, Curitiba, PR, Brasil. ${ }^{2}$ Centro Universitário Uningá, Faculadade de Medicina, Maringá, PR, Brasil. ${ }^{3}$ Universidade Positivo, Departamento de Medicina, Curitiba, PR, Brasil.

Corresponding author: Prof. Renato M. Nisihara. Orcid: 0000-0002-1234-8093. E-mail: renatonisihara@gmail.com 
toantibodies (anti-tissue transglutaminase and/or anti-endomysial antibodies), and confirmation by histological findings of the duodenal mucosa, in accordance with the Marsh classification ${ }^{(13)}$.

Frequency analyses were performed through Chi-squared and Fisher's exact tests using Graph Pad Prism 5.0 (GraphPad software Inc., La Jolla, CA, USA). A $P<0.05$ was considered statistically significant.

\section{RESULTS}

A total of 213 patients with CD at diagnosis were examined: 52 males (mean age, 40.0 years; range, $12-70$ years) and 161 females (mean age, 41.4 years; range, 12-87 years). The proportion of females and males with CD was $3: 1$.

The patients were divided into the following groups according to sex and age:

FEMALES: Group FI (12-20 years), Group FII (21-30 years), Group FIII (31-40 years), Group FIV (41-50 years), Group FV (51-60 years), and Group FVI (more than 61 years).

MALES: Group MI (12-20 years), Group MII (21-30 years), Group MIII (31-40 years), Group MIV (41-50 years), Group MV (51-60 years), and Group MVI (more than 61 years)

TABLE 1 summarizes the data regarding age, sex, and occurrence of IMDs the study cohort. In total, $54.4 \%$ of the patients with CD presented with IMDs. No significant difference was observed in the total prevalence between females and males $(P=0.22)$. However, female patients aged 51-60 years exhibited significantly higher frequency of IMDs than males $(P=0.0002)$.

TABLE 1. Distribution of age, gender and immune mediated diseases (IMDs) in the groups of the 213 studied patients.

\begin{tabular}{|c|c|c|c|c|c|}
\hline Group/Age & $\begin{array}{l}\text { Female } \\
(n=161)\end{array}$ & $\begin{array}{l}\text { Male } \\
(\mathrm{n}=52)\end{array}$ & $\begin{array}{l}\text { IMDs at } \\
\text { diagnosis } \\
\text { Female } \\
\text { n }(\%)\end{array}$ & $\begin{array}{c}\text { IMDs at } \\
\text { diagnosis } \\
\text { Male } \\
\mathrm{n}(\%)\end{array}$ & $P^{*}$ \\
\hline $\begin{array}{l}\text { I (12-20 years) } \\
n=33\end{array}$ & 25 & 8 & $12(48.0)$ & $2(25.0)$ & 0.41 \\
\hline $\begin{array}{l}\text { II ( } 21-30 \text { years) } \\
\mathrm{n}=33\end{array}$ & 26 & 7 & $15(57.7)$ & $6(85.7)$ & 0.22 \\
\hline $\begin{array}{l}\text { III ( } 31-40 \text { years) } \\
\mathrm{n}=48\end{array}$ & 36 & 12 & $17(47.2)$ & $7(58.3)$ & 0.73 \\
\hline $\begin{array}{l}\text { IV ( } 41-50 \text { years) } \\
\mathrm{n}=48\end{array}$ & 37 & 11 & $20(54.0)$ & $6(54.5)$ & 0.72 \\
\hline $\begin{array}{l}\mathrm{V}(51-60 \text { years }) \\
\mathrm{n}=29\end{array}$ & 21 & 8 & $20(95.2)$ & $3(18.8)$ & 0.002 \\
\hline $\begin{array}{l}\text { VI (> } 61 \text { years) } \\
\mathrm{n}=22\end{array}$ & 16 & 6 & $8(50.0)$ & 0 & 0.05 \\
\hline Total & $\mathrm{n}=161$ & $\mathrm{n}=52$ & $92(57.1)$ & $24(46.1)$ & 0.22 \\
\hline
\end{tabular}

* Fisher's Exact Test comparing gender.
TABLE 2 presents the number and percentages of reported IMDs according to sexes. IMDs were significantly more frequent in females $[97 / 161(60.2 \%)]$ than in males $[22 / 52(42.3 \%)](P=0.025)$. Statistical analysis revealed that dermatitis herpetiformis $(\mathrm{DH})$ was significantly more prevalent in males $(P=0.029)$, whereas atopy was significantly more prevalent in females $(P=0.024)$.

TABLE 2. Immuno mediated diseases diagnosed in celiac patient in according to gender.

\begin{tabular}{lccc}
\hline Immuno mediated disease & $\begin{array}{c}\text { Female } \\
(\mathbf{n}=161)\end{array}$ & $\begin{array}{c}\text { Male } \\
(\mathbf{n}=52)\end{array}$ & $\boldsymbol{P}$ value * \\
\hline Hypothyroidism & $36(22.3)$ & $6(11.5)$ & $\mathrm{ns}$ \\
Dermatitis Herpetiformis & $15(9.4)$ & $11(21.1)$ & 0.029 \\
Atopy & $15(9.4)$ & 0 & 0.024 \\
Lymphocitic colitis & $6(3.7)$ & $2(3.8)$ & $\mathrm{ns}$ \\
Endometriosis & $5(3.1)$ & 0 & $\mathrm{~ns}$ \\
Autoimmune gastritis & $4(2.5)$ & 0 & $\mathrm{~ns}$ \\
Diabetes mellitus type 1 & $3(1.9)$ & $1(1.9)$ & $\mathrm{ns}$ \\
Autoimmune hepatitis & $2(1.2)$ & 0 & $\mathrm{~ns}$ \\
Psoriasis & $2(1.2)$ & 0 & $\mathrm{~ns}$ \\
Lupus erythematosus & $2(1.2)$ & 0 & $\mathrm{~ns}$ \\
Raynaud phenomem & $2(1.2)$ & 0 & $\mathrm{~ns}$ \\
Alopecia areata & $1(0.6)$ & 0 & $\mathrm{~ns}$ \\
Vitiligo & $1(0.6)$ & 0 & $\mathrm{~ns}$ \\
Addison's disease & $1(0.6)$ & $1(1.9)$ & $\mathrm{ns}$ \\
Inflammatory bowel disease & $1(0.6)$ & $1(1.9)$ & $\mathrm{ns}$ \\
Lymphoma & $1(0.6)$ & 0 & $\mathrm{~ns}$ \\
Total & $97(60.2)$ & $22(42.3)$ & 0.025 \\
\hline
\end{tabular}

* Fisher's exact test.

In addition, information regarding 151 first-degree relatives ( $\mathrm{n}=103 ; 68.2 \%$ females) with IMDs, as reported by the patients at diagnosis, was also analyzed. TABLE 3 lists IMDs identified in the first-degree relatives of the study cohort. IMDs detected in the first-degree relatives were similar to those detected in the patients. $\mathrm{CD}$ was more prevalent in female first-degree relatives $(P=0.045)$. Atopy was more frequent in male first-degree relatives $(P=0.002)$.

The frequency of different IMDs was higher in female relatives (mothers, sisters, and daughters) than in male relatives (TABLE 4).

\section{DISCUSSION}

In the present Brazilian study, the proportion of females and males with $C D$ was $3: 1$, which is consistent with that in an Italian study by Ciacci et al. ${ }^{(14)}$. Notably, females consult doctors more frequently than males, present with more symptoms, and are more prone to develop AIDs $^{(15)}$.

Certain sex-based immunological differences are present throughout life, whereas others are only apparent after puberty 
TABLE 3. Immuno mediated diseases in relatives of the studied patients ( $\mathrm{n}=52$ males and $\mathrm{n}=161$ females).

\begin{tabular}{|c|c|c|c|}
\hline $\begin{array}{l}\text { Immuno } \\
\text { mediated diseases } \\
\text { (IMDs) }\end{array}$ & $\begin{array}{l}\text { Celiac } \\
\text { patient's } \\
\text { sex } \\
\end{array}$ & $\begin{array}{l}\text { First degree } \\
\text { relative with } \\
\text { IMDs n }(\%)\end{array}$ & $\begin{array}{l}\text { First degree } \\
\text { relative with } \\
\text { IMDs sex }\end{array}$ \\
\hline \multirow{2}{*}{ Hypothyroidism } & $\mathrm{F}$ & $48(29.8 \%)$ & $43 \mathrm{~F} ; 5 \mathrm{M}$ \\
\hline & M & $12(23.0 \%)$ & $11 \mathrm{~F} ; 1 \mathrm{M}$ \\
\hline \multirow{2}{*}{ Celiac disease * } & $\mathrm{F}$ & $30(18.6 \%)$ & $25 \mathrm{~F} ; 5 \mathrm{M}$ \\
\hline & M & $9(17.3 \%)$ & $8 \mathrm{~F} ; 1 \mathrm{M}$ \\
\hline \multirow{2}{*}{ Atopy ${ }^{\#}$} & $\mathrm{~F}$ & $6(3.7 \%)$ & $3 \mathrm{~F} ; 3 \mathrm{M}$ \\
\hline & M & $7(13.4 \%)$ & $3 \mathrm{~F} ; 4 \mathrm{M}$ \\
\hline \multirow{2}{*}{$\begin{array}{l}\text { Rheumatoid } \\
\text { arthritis }\end{array}$} & $\mathrm{F}$ & $4(2.5 \%)$ & $4 \mathrm{~F} ; 0 \mathrm{M}$ \\
\hline & M & $4(7.7 \%)$ & $3 \mathrm{~F} ; 1 \mathrm{M}$ \\
\hline \multirow{2}{*}{$\begin{array}{l}\text { Diabetes mellitus } \\
\text { type } 1\end{array}$} & $\mathrm{~F}$ & $3(1.8 \%)$ & $0 \mathrm{~F} ; 3 \mathrm{M}$ \\
\hline & M & $3(5.7 \%)$ & $2 \mathrm{~F} ; 1 \mathrm{M}$ \\
\hline \multirow{2}{*}{ Crohn's disease } & $\mathrm{F}$ & $3(1.8 \%)$ & $1 \mathrm{~F} ; 2 \mathrm{M}$ \\
\hline & M & 0 & \\
\hline \multirow{2}{*}{$\begin{array}{l}\text { Dermatitis } \\
\text { herpetiformis }\end{array}$} & $\mathrm{F}$ & $2(1.2 \%)$ & $1 \mathrm{~F} ; 1 \mathrm{M}$ \\
\hline & M & $2(3.8 \%)$ & $1 \mathrm{~F} ; 1 \mathrm{M}$ \\
\hline \multirow{2}{*}{ Vitiligo } & $\mathrm{F}$ & $1(0.6 \%)$ & $1 \mathrm{~F} ; 0 \mathrm{M}$ \\
\hline & M & $1(1.9 \%)$ & $1 \mathrm{~F} ; 0 \mathrm{M}$ \\
\hline \multirow{2}{*}{ Psoriasis } & $\mathrm{F}$ & $1(0.6 \%)$ & $0 \mathrm{~F} ; 1 \mathrm{M}$ \\
\hline & M & 0 & 0 \\
\hline \multirow{2}{*}{$\begin{array}{l}\text { Lupus } \\
\text { erythematosus }\end{array}$} & $\mathrm{F}$ & $1(0.6 \%)$ & $1 \mathrm{~F} ; 0 \mathrm{M}$ \\
\hline & M & $1(1.9 \%)$ & $1 \mathrm{~F} ; 0 \mathrm{M}$ \\
\hline \multirow{2}{*}{ Lymphoma } & $\mathrm{F}$ & $1(0.6 \%)$ & $0 \mathrm{~F} ; 1 \mathrm{M}$ \\
\hline & M & $1(1.9 \%)$ & $1 \mathrm{~F} ; 0 \mathrm{M}$ \\
\hline
\end{tabular}

Total

$151 / 213=70.9 \%$

${ }^{*} P=0.045$ Chi-Square test. ${ }^{\#} P=0.002$ Fisher Exact test. F: female; M: male. All the other comparison: $P=$ not significant.

and before reproductive senescence, suggesting the involvement of both genes and hormones ${ }^{(16)}$. CD can be diagnosed at any age, but a delay in diagnosis is frequently unrecognized in young adults and older patients. In our investigation, 9.9\% (16/161) of the females and $11.5 \%(6 / 52)$ of the males were diagnosed after 61 years of age $^{(17)}$. Substantial diagnostic delay in CD is associated with poor clinical outcomes, and it is occurs more frequent in females ${ }^{(18)}$. Bai et al. ${ }^{(19)}$ studied 323 patients ( 211 female and $112 \mathrm{men}$ ) in the USA and reported no sex-based differences in the age at diagnosis or the mode of presentation, which is consistent with our findings.

The total number of associated IMDs (57.1\% in females and $46.1 \%$ in males) was higher than that described in previous reports $(15 \%-30 \%)^{(20)}$. This high prevalence could be partially explained by the shared genes in immunological pathways between $C D$ and other IMDs ${ }^{(21)}$. Based on the findings of between-group comparison of age, the diagnosis of CD in females later in their lives can hypothetically predispose them to more IMDs as a result of prolonged inflammation ${ }^{(22)}$. Sategna-Guidetti et al. ${ }^{(23)}$ have reported that the duration of gluten exposure in adults with CD was not correlated with the risk of autoimmune disorders, which differs from our findings.

Notable, young patients in the present study (Groups FI and MI) were diagnosed with IMDs before the diagnosis of CD, which is consistent with a report by Demirezer et al. in Turkey ${ }^{(24)}$. Demirezer and colleagues identified female sex, family history of AIDs as risk factors for IMDs, as presented in the present study.

In the present study, DH was more prevalent in males than in females, which is similar to the findings of other studies ${ }^{(16,25)}$. Other dermatological diseases, such as psoriasis, vitiligo, and alopecia areata, are diagnosed before $C D$. Interestingly, benefits of a gluten-free diet have been described ${ }^{(26)}$ in these diseases, although the cause is not known.

The close association between CD and endocrine autoimmunity has been frequently reported in the literature, thus warranting a broader immune genetic study given that patients with $\mathrm{CD}$ and their relatives present with endocrine autoimmune syndromes ${ }^{(27)}$. In the general population, thyroid disease (TD) is frequent in females after 40 years of age, as shown in this study. Conversely, TD is generally frequent in males after 60 years of age. However, in our study, TD was diagnosed relatively early, as described by another studies ${ }^{(28)}$. Diabetes mellitus type I was diagnosed before CD in two young male patients (age, 14 and 21 years). However, two females (age, 51 and 54 years) undergoing treatment for diabetes mellitus type I were referred to a gastroenterologist later in their life and were diagnosed as having CD. Both females were received treatments for hypothyroidism, and one of them developed DH. Interestingly, three or four IMDs occurring in the same patient is a rare association ${ }^{(29)}$. Compared with controls, patients with $\mathrm{CD}$ were 11.4 times more likely to develop Addison's disease before or after the diagnosis of $\mathrm{CD}^{(24)}$. In this study, one female (age, 49 years) and one male (age, 61 years) presented with Addison's disease at the diagnosis of CD.

Ludvigsson et al. ${ }^{(30)}$ have reported that patients with $\mathrm{CD}$ were at a threefold increased risk of developing systemic lupus erythematous (SLE). In the present study, two patients were diagnosed with SLE before the diagnosis of CD was confirmed. In our previous study, the endomysial antibody was more frequently positive in patients with SLE than in controls, particularly those with discoid lesions ${ }^{(31)}$. Raynaud phenomenon was observed in two patients; both showed the classic tricolor phenomenon and symmetrical bilateral involvement of hands and feet ${ }^{(32)}$. No other autoimmune rheumatic disease was detected.

Concomitant CD and endometriosis may render the diagnosis difficult due to the overlapping symptoms, such as abdominal pain, bowel changes, spontaneous abortion, and infertility ${ }^{(33)}$. In the present study, endometriosis was diagnosed in 3.1\% of the patients $(5 / 161)$ at the diagnosis of CD. In another region of Brazil, Aguiar et al. ${ }^{(34)}$ have reported $2.5 \%$ prevalence of CD in 120 females with endometriosis and $0.6 \%$ in 1500 healthy females. Thus, commonalities exist between CD and endometriosis by altered Th1 immune response pattern arising from the polymorphic genes of interleukin-18 and interferon-gamma ${ }^{(35)}$. Marziali et al. ${ }^{(35)}$ have recommended a gluten-free diet as a new strategy for the management of painful endometriosis-related symptoms. 
TABLE 4. Frequency of immuno mediated diseases in first-degree relatives of celiac patients.

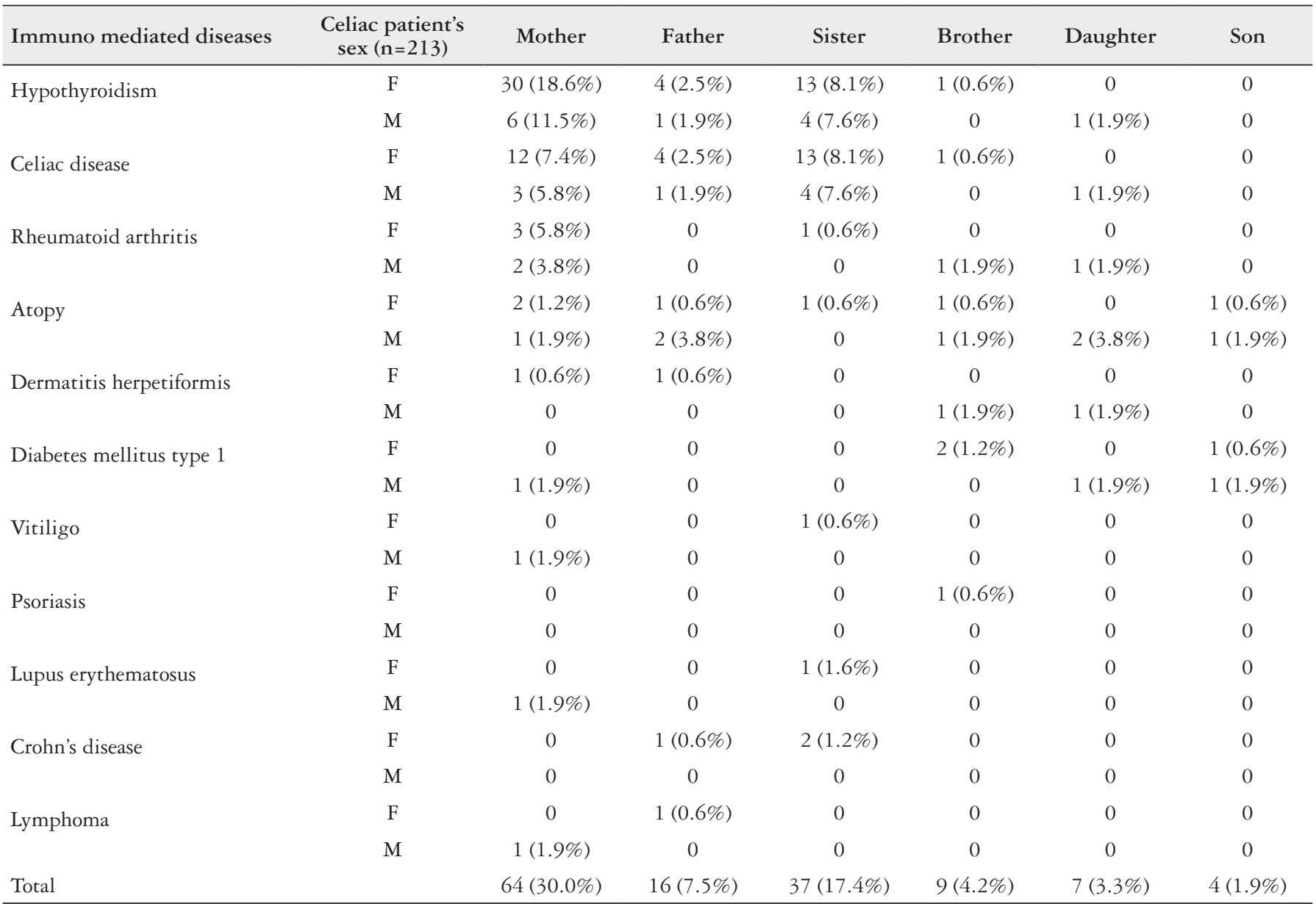

The association between atopy and CD has not been satisfactorily established. Our patients reported asthma, eczema, rhinitis, or conjunctivitis. In a study in Sweden, Enroth et al. ${ }^{(36)}$ have reported a high level of self-reported allergies $(42.3 \%)$ in patients with CD; this finding was inversely correlated with age and was more frequent in young patients, emphasizing heritability. In our study, only females $(9.4 \%)$ reported any atopic manifestations.

Several authors have shown that self-reports are often accurate $^{(9)}$, and the family history can be effectively captured based on patient reports ${ }^{(12)}$. Relatives of CD patients exhibit a higher prevalence of IMDs compared with the relative of controls. Moreover, relatives of $C D$ patients with IMDs are at $25 \%$ higher risk of having undiagnosed $\mathrm{CD}$, and they must be screened for $\mathrm{CD}^{(8)}$. However, Roy et al. ${ }^{(37)}$ have described that physicians treating patients with CD seldom recommend routine screening of the first-degree relatives.

$\mathrm{CD}$ was present in first-degree relatives, being more prevalent in mothers, sisters, and daughters. These results are in accordance with previous reports of our group ${ }^{(38)}$. In a meta-analysis, Vaquero et al. ${ }^{(39)}$ have described the prevalence of $\mathrm{CD}$ and its risk in the first-degree relatives according to geographic areas; a lower risk was observed in South America than in Asia, North America, and Europe. However, findings of a few studies, including two in Argentina (Buenos Aires 1977 and 1999) and five in Brazil, which showed differences in the regions of these countries and different racial mixtures of the population, should also be considered. We speculate that the findings of a majority of these studies were not applied in the clinical setting.

Diseases detected in the first-degree relatives were almost the same as those detected in patients with $C D$ of both sexes. A higher frequency of IMDs was reported in females, which is in corroboration with the reported literature ${ }^{(7)}$.

\section{CONCLUSION}

The frequency of IMDs in CD patients was similar in all age groups and both sexes, except women diagnosed with CD after 51 years of age presented with an increased frequency of IMDs compared with males. DH was more prevalent in males, whereas atopy was more prevalent in females. No difference was observed in the type of IMDs between the first-degree relatives of both sexes.

\section{Authors' contribution}

Kotze LMS and Kotze LR: study concept and design; acquisition of data; analysis and interpretation of data; drafting of the manuscript. Moreno I: acquisition of data; analysis and interpretation of data; drafting of the manuscript. Nisihara R: study concept and design; analysis and interpretation of data; drafting of the manuscript; statistical analysis. 
Kotze LMS, Kotze LR, Moreno I, Nisihara R. Doenças imunomediadas em pacientes com doença celíaca e em seus familiares: um estudo comparativo entre idade e sexo. Arq Gastroenterol. 2018;55(4):346-51.

RESUMO - Contexto - Até 15\% das outras doenças imunomediadas (DIMs) podem ocorrer em pacientes com doença celíaca ao longo de suas vidas e estão associados a múltiplos fatores, incluindo sexo e níveis de hormônios sexuais. Além disso, o sexo está associado a diferenças na apresentação, início, progressão e desfecho das doenças. Objetivo - Investigar a prevalência de DIMs ao diagnóstico de doença celíaca e em seus familiares de primeiro grau e comparar os resultados entre sexo feminino e masculino em diferentes idades. Métodos - Estudo retrospectivo incluindo pacientes brasileiros com diagnóstico de doença celíaca que realizaram acompanhamento com o mesmo médico no período de janeiro 2012 a janeiro de 2017. Dados demográficos e histórico médico foram coletados através de um questionário auto administrado e prontuários médicos dos pacientes envolvidos. No total, 213 pacientes eram portadores de doença celíaca, dos quais 52 do sexo masculino (idade média 40,0 anos) e 161 do sexo feminino (idade média 41,4 anos). Os pacientes foram divididos em dois grupos de acordo com o sexo e idade. Resultados - DIMs foram observadas em $60,2 \%$ das pacientes femininas (97/161) e 42,4\% dos pacientes masculinos (22/52; $P=0,22)$. Entretanto, a frequência de DIMs foi significantemente maior em pacientes do sexo feminino com idade entre 51-60 anos que em pacientes masculinos da mesma idade $(P=0,0002)$. Dermatite herpetiforme apresentou maior prevalência no sexo masculino $(P=0,02)$, enquanto atopia obteve maior prevalência nas pacientes do sexo feminino $(P=0,02)$. DIMs observadas em familiares de primeiro grau foram similares as encontradas nos pacientes $(70,9 \% ; P<0,001)$, com um maior número observado em familiares femininos. Conclusão - A frequência de DIMs em pacientes com doença celíaca foi similar nos grupos etários e ambos sexos, exceto as mulheres com diagnóstico de doença celíaca após a idade de 51 anos, as quais apresentaram um aumento na frequência de DIMs em comparação com os pacientes do sexo masculino. Dermatite herpetiforme apresentou maior prevalência em pacientes do sexo masculino, enquanto que atopia foi mais prevalente no sexo feminino. Em relação ao sexo, não foi observada diferença no tipo de DIMs observada entre os familiares de primeiro grau.

DESCRITORES - Doença celíaca. Doenças autoimunes. Fatores sexuais. Fatores etários. Dermatite herpetiforme.

\section{REFERENCES}

1. Viljamaa M, Kaukinen K, Huhtala H, Kyronpalo S, Rasmussen M, Collin P Coeliac disease, autoimmune diseases and gluten exposure. Scand J Gastroenterol. 2005;40:437-43.

2. Fasano A. Systemic autoimmune disorders in celiac disease. Current Opinion in Gastroenterology. 2006;22:674-9.

3. Kumar V, Wijmenga C, Viljamaa M, Kaukinen K, Huhtala H, Kyronpalo S, Rasmussen M, Colin P. Coeliac disease, autoimmune diseases and gluten exposure. Scand J Gastroenterol. 2005;40:437-43.

4. Denham JM, Hill ID. Celiac disease and autoimmunity: Review and controversies. Curr Allergy Asthma Rep. 2013;13:347-53.

5. Spijkerman M, Tan IL, Kolkman JJ, Withoff S, Wijmanga C, Visschedijk MC, et al. A large variety of clinical features and $\mathrm{H}$ in celiac disease - A cohort study in the Netherlands. Dig Liver Dis. 2016;48:499-505.

6. Nussinovitch U, Shoenfeld Y. The role of gender and organ specific autoimmunity. Autoimmun Rev. 2012;11:A377-385.

7. Pennell LM, Galligan CL, Fish EN. Sex affects immunity. J Autoimmun. 2012; 38:J282-291.

8. Petaros P, Martelossi S, Tommasini A, Torre G, Caradonna M, Ventura A. Prevalence of autoimmune disorders in relatives of patients with celiac disease. Dig Dis Sci. 2002;47:1427-31.

9. Cataldo F, Marino V. Increased prevalence of autoimmune diseases in first-degree relatives of patients with celiac disease. J Pediatr Gastroenterol, Nutr. 2003;36:470-3.

10. Neuhausen SL, Steele L, Ryan S, Mousavi M, Pinto M, Osann KE, et al. Co-occurrence of celiac disease and other autoimmune diseases in celiac and their first-degree relatives. J Autoimmunity. 2008;31:160-5.

11. Bergmann MM, Jacobs EJ, Hoffmann K, Boeing H. Agreement of self-reported medical history: Comparison of an in-person interview with a self-administered questionnaire. Eur J Epidemiol. 2004;19:411-6.

12. Bensen JT, Liese AD, Rushing JT, Province M, Folsom AR, Rich SS, et al. Accuracy of proband reported family history: The NHBI Family Heart Study (FHS). Genetic Epidemol. 1999;17:141-50.

13. Marsh MN. Mucosal pathology in gluten sensitivity. In: Marsh MN. Coeliac disease. Oxford: Blackwell Scientific Publications; 1992. p. 136-91.

14. Ciacci C, Cirillo M, Sollazzo R, Savino G, Sabbatini F, Mazzacca G. Gender and clinical presentation in adult celiac disease. Scand J Gastroenterol. 1995;30:1077-81.

15. Bardella MT, Fredella C, Saladino V, Trovato C, Cesana BM, Quatrini M, et al. Gluten intolerance: Gender-and age-related differences in symptoms. Scand J Gastroenterol. 2005;40:15-9.

16. Klein SL, Flanagan KL. Sex differences in immune responses. Nat Rev Immunol. 2016;16:626-38.
17. Kotze LM, Nisihara RM, Utiyama SR, Kotze LR. Celiac disease in older Brazilians. J Am Geriat Soc. 2011;59:1548-50.

18. Vavricka SR, Vadasz N, Stotz M, Lehmann R, Studerus D, Greuter T, et al Coeliac disease diagnosis still significantly delayed - Doctor's but not patient's delay responsive for the increased total delay in women. Dig Liver Dis 2016;pii:S1590-8658:39475-3.

19. Bai D, Brar P, Holleran S, Ramakrishnan R, Green PHR. Effect of gender on the manifestations of celiac disease: evidence for greater malabsorption in men. Scand J Gastroenterol. 2005;40:183-7.

20. Lauret E, Rodrigo L. Celiac disease and autoimmune-associated conditions. BioMed Res Int. 2013;2013:127589.

21. Zhernakova PD, van Diemen CC, Wijmenga C. Detection shared pathogenesis from the shared genetics of immune-related diseases. Nature Reviews: Genetics. 2009; $10: 43-55$

22. Ventura A, Magazzu G, Greco L. Duration of exposure to gluten and risk for autoimmune disorders in patients with celiac disease. Gastroenterology. 1999;117:297-303.

23. Sategna Guidetti C, Solerio E, Scaglione N, Aimo G, Mengozzi G. Duration of gluten exposure in adult coeliac disease does not correlate with the risk for autoimmune disorders. Gut. 2001;49:502-5.

24. Demirezer BA, Akın FE, Tahtacı M, Tayfur Yürekli Ö, Köseoğlu H, Erten Ş, et al. Risk Factors for Polyautoimmunity among Patients with Celiac Disease: A Cross-Sectional Survey. Digestion. 2015;92:185-91.

25. Kotze LM, Vecchia LA, Nisihara RM, Kotze LR. Dermatitis herpetiformis in Brazilian male celiac disease patients: A case series. Rev Esp Enferm Dig. 2014;106:562-4

26. Juzlova K, Votrubova J, Dzambova M, Gopfertova D, Hercogova J, Smerhovsky Z. Gastrointestinal comorbidities in patients with psoriasis in the Czech Republic: The results of 189 patients with psoriasis and 378 controls. Biomed Pap Med Fac Univ Palacky Olomouc Czech Repub. 2016;160:100-5.

27. Kahaly GJ, Schuppan D. Celiac disease and endocrine autoimmunity. Dig Dis 2015;33:155-61.

28. Kotze LM, Nisihara RM, Utiyama SR, Piovezan GC, Kotze LR. Thyroid disorders in Brazilian patients with celiac disease. J Clin Gastroenterol. 2006;40:33-6.

29. Boccuti V, Perrone A, DÍntrono A, Campobasso A, Sangineto M, Sabba C. An unusual association of three autoimmune disorders: celiac disease, systemic lupus erythematosus and Hashimoto's thyroiditis. Auto Immun Highlights. 2016;7:7.

30. Ludvigsson JF, Rubio-Tapa A, Chowdhary V, Murray JÁ, Simard JF. Increasesd risk of systemic lupus erythematosus in 29,000 patients with biopsy-verified celiac disease. J Rheumatol. 2012;39:1964-70. 
31. Piccelli V, Skare T, Nisihara RM, Kotze L, Messias-Reason I, Utiyama S. Spectrum of autoantibodies for gastrointestinal autoimmune disease in systemic lupus erythematosus patients. Lupus. 2013;22:1150-5.

32. Thonhofer R, Trummer M, Siegel C. Capillaroscopy shows an active patter of scleroderma in celiac disease. Scand J Rheumatol. 2010;39:438-9.

33. Mormile R, Vittori G. Celiac disease and endometriosis: what is the nexus? Arch Gynecol Obstet. 2013;288:1197-8.

34. Aguiar FM, Melo SB, Galvão LC, Rosa-e-Silva JC, dos Reis RM, Ferriani RA. Serological testing for celiac disease in women with endometriosis. A pilot study. Clin Exp Obstet Gynecol. 2009;36:23-5.

35. Marziali M, Venza M, Lazzaro S, Lazzaro A, Micossi C, Stolfi VM. Gluten-free diet: a new strategy for management of painful endometriosis related symptoms? Minerva Chir. 2012;67:499-504
36. Enroth S, Dalbom I, Hansson T, Hohansson A, Gyllensten U. Prevalence and sensitization of atopic allergy and coeliac disease in the Northern Sweden Population Healthy Study. Int J Circumpolar Health. 2013;5:72.

37. Roy A, Smith C, Daskalakis C, Voorhees K, Moleski S, DiMarino AJ, Kastenberg D. Physicians Caring for Celiac Patients do not Routinely Recommend Screening of First-Degree Family Members. J Gastroenterol Hepatol Res. 2015;4: 1838-43.

38. Kotze LMS, Utiyama SRR, Nisihara RM, Zeni MP, de Sena MG, Amarante HM. Antiendomysium antibodies in Brazilian patients with celiac disease and their first-degree relatives. Arq. Gastroenterol. 2001;38:94-103.

39. Vaquero L, Caminero A, Nuñez A, Hernando M, Iglesias C, et al. Coeliac disease screening in first-degree relatives on the basis of biopsy and genetic risk. Eur $\mathrm{J}$ Gastroenterol Hepatol. 2014;26:263-7. 